USSR

Academy Weighs Protest

by our Washington Correspondent

ThE National Academy of Sciences is considering lodging a protest with the government of the USSR over the persecution of Professor B. G. Levich. An eminent electrochemist, Levich was recently dismissed from his position as head of the Institute of Electrochemistry, deprived of his professorship at the University of Moscow and banned from taking part in the International Biophysical Congress in Moscow last month, presumably because he had applied for a permit to emigrate to Israel (see Nature, 238, $365 ; 1972$ ).

The form of the Academy's protestor, indeed, if there is to be one-has not yet been finally decided. But the foreign secretary of the academy, Dr Harrison Brown, has been meeting with officials of learned societies in Europe, including the Royal Society, during the past two weeks to sound out the prospects for lodging a combined protest. The decision to explore such a possibility was taken at an NAS council meeting last month, but whether or not the protest should be made public was not decided. The issue was, however, resolved for the academy last week when news of the possible protest appeared in the press.

If the protest is made, it will probably steer clear of condemning the general policies of the USSR concerning emigration to Israel, but it will concentrate on the harassment of scientists, particularly the situation in which an eminent and productive scientist such as Levich is prevented from working for overtly political reasons. Similar protests from the academy have in the past been made on an individual basis, and they have not been made public.

In the meantime, the case of another Soviet scientist who has been persecuted for similar reasons seems to have taken a turn for the worse. Dr Alexander Ya. Lerner, who was summarily dismissed nearly a year ago from his professional positions in the Moscow Institute of Control Sciences and from his professorship at the University of Moscow after he had applied for permission to emigrate to Israel (see Nature, 235, 121 ; 1972 ), has also been prevented from accepting an invitation to give a series of lectures in Italy and he was recently refused permission to attend the Congress of the International Federation of Automatic Control (IFAC) in Paris.

Although, in view of the previous harassment of Professor Lerner, it is not surprising that he was denied permission to travel outside the Soviet Union to international conferences, a particularly unsavoury aspect of the affair is what seems to be a blatant attempt by the government of the USSR to interfere with the internal affairs of IFAC. Lerner is vice-chairman of the IFAC Committee on Applications, but Dr V. A. Trapeznikov, his former director at the Institute of Control Sciences, has demanded that he be removed from this position. The demand has been refused.

Lerner was refused permission to attend the IFAC Congress because of "insufficient foreign currency", in spite of the fact that all his expenses would have been paid by IFAC. Moreover, to add insult to injury, Trapeznikov asked that the paper Lerner was intending to deliver at the congress be removed from the programme because it was found by his co-author to be based on errors. The programme committee screened the paper twice, however, and denied the request.

\section{CARDIOVASCULAR DISEASES More Funds for Research}

by our Washington Correspondent CONGRESS last week finally passed and sent to President Nixon a bill calling for massive increases in expenditure on research into diseases of the heart, lungs and blood vessels. Originally sponsored in the House of Representatives by Paul G. Rogers of Florida and in the Senate by Senator Edward M. Kennedy of Massachusetts, the bill launches a crusade against diseases of the cardiovascular system similar to the crusade against cancer. It calls for expenditures of $\$ 1,380$ million over the next three years, mostly administered by the director of the National Heart and Lung Institute, part of the National Institutes of Health.

Apart from increasing the budget of the National Heart and Lung Institute, the bill also calls for the establishment of fifteen new centres for basic and clinical research into diagnosis, prevention and treatment of cardiovascular diseases, together with fifteen new research centres similarly devoted to chronic diseases of the lungs.

If President Nixon signs the bill-and it is unlikely that he will veto it in election year, even though it calls for more expenditure than he would like - the money entailed would still have to be appropriated by the appropriations committees. The committees are now in the throes of drawing up fresh appropriations for the National Institutes of Health after President Nixon vetoed the appropriations for the Department of Health, Labor and Welfare for the present fiscal year, and they are under orders to trim down their original bill considerably. That bill, however, contained some $\$ 75$ million less for the National Heart and Lung Institute than the bill passed last week requested. There is therefore little chance that the sponsors will get all they ask for.

\section{AUTOMOBILES} GM Goes Rotary

by our Washington Correspondent

DETROIT has been going through a tough time lately. Not only must automobile manufacturers produce cars that meet stringent air pollution control standards in 1975, but last week the Administration turned down their request for a price increase on 1973 models. With all the concern over air pollution control devices and the industry's claims of financial hardships, this would seem a bad time for major innovations in the motor industry. But, on the very day that its request for a price increase was turned down, General Motors announced that it would offer rotary engines in its popular Chevrolet Vega cars about two years from now.

Although GM would then be the only American motor manufacturer to produce cars with the Wankel engine, its decision to go rotary was prompted to some extent by the success on the West Coast of the Japanese Mazda. Another factor is the rush to meet the 1975 air pollution requirements, for although the Wankel engine is not inherently clean, it may be more adaptable to the catalytic converters on which the motor industry now seems to be pinning its hopes. One problem with the catalytic converters is that they are bulky, which makes them difficult to reconcile with the industry's obsession with body styling, but the Wankel engine is only about two-thirds the size of a conventional engine with comparable power, so that the converters can be fitted without sacrificing advertising appeal.

Named after its German inventor, Felix Wankel, the rotary engine runs on a mixture of air and gasoline, but it differs from the conventional automobile engine chiefly in the combustion chamber. Instead of pistons, the central part of the engine consists of three triangular rotors which rotate in an elliptical chamber to compress the fuel mixture, which is ignited by spark plugs.

The engine contains many fewer parts than the conventional piston engine, and it is reputed to be quieter, but it has the disadvantage of being much more costly to produce. Although GM spokesmen are reluctant to discuss costs at present, they said last week that the company is attempting to improve the durability of the inside wall of the chamber and the apex of the triangular rotors which are in contact with it, and which take the chief frictional wear. At least one major cost of the engine to GM is also the licence fee that is being paid to the West German patent holders, for worldwide rights. GM is reported to be paying Audi/NSU $\$ 50$ million for the rights. 